\title{
Tailoring sugarcane for smart canopy architecture
}

\section{Introduction}

Sugarcane is a crop of great economic importance in sugar and biomass dependent economies because of its exceptionally high productivity and its ability for storage of high concentration of sucrose. It is primarily a crop of tropical and sub-tropical regions of the world. However, the ever increasing demand for sugar and bio fuels have driven the expansion of sugarcane production throughout the world and it is presently being cultivated in nearly 100 countries worldwide with a cultivation area of 23.8 million ha and produces 1685 million tonnes cane with an average cane productivity of 71 tha1. It is the most productive crop with biomass accumulation rates as high as $550 \mathrm{~kg}$ ha-1day-1 and provides third highest quantity of plant calories in human diet after rice and wheat. Despite the productivity of sugarcane being highest among crop plants, there exists wide gap in its theoretical yield (470 $\mathrm{mt} \mathrm{ha-}^{-1}$ year- $\left.{ }^{-1}\right)$ and productivity achieved at field (168 $\mathrm{mt} \mathrm{ha-}^{1}$ year- $\left.{ }^{1}\right)$ with average cane yield hovering around 65 tonnes ha- ${ }^{-}$. In India, which is second largest sugarcane producer in the world after Brazil, this productivity lingers around $28 \%$ of the theoretical maximum. The prevalence of short duration crop cultivation practices like- spring and late planting of sugarcane further aggravate the situation. Besides, numerous physiological constraints contributing to low productivity, short duration crop practices mainly succumb to two serious constraints in form short crop growth period and prevalence of high and desiccating temperatures coinciding with the crucial germination and tillering phases. This reduces the crop yields to 30-40 tha- ${ }^{1}$ and further broadens the gap between theoretical yield and actual yield. Filling the wide yield gaps in sugarcane cropping system is thus a critical target for which realistic measures are required.

Further the amount of land dedicated to sugarcane farming is shrinking every year. And with burgeoning human population, the demand for sugar and it's by-products are increasing day by day. Though attempts in past decades have led to significant increase in sugarcane productivity, the future demands will have to be addressed through novel approaches for enhancing biomass and sugar production. At present, sugarcane crop in a growth cycle of 12 months;

1. Approximately produces 80,000 to 100000 plants ha- ${ }^{-1}$ (through $33 \%$ per cent germination in 45 days after planting with about 40000 plants per ha).

2. The plant population at 90 days after planting (DAP) isabout $60,000-70,000$ plants per ha which extends upto $\mathrm{T}_{\text {max }}$ of $1,75,000$ plants per ha at 210 DAP.

3. The number of tillers at $90 \mathrm{DAP}$ are crucial as they contribute about $45 \%$ towards number of mill able canes (NMC) at harvest stage (360 DAP).

4. The plants obtained at $\mathrm{T}_{\max }$ undergo tiller cessation by 50-60 $\%$, leading to reduction in plant numbers in clumps and finally culminating into decreased NMC (80,000- 100,000 per ha) at harvest stage.

5. This tiller cessation causes about $50 \%$ loss in accumulated dry matter and sucrose contents.

6. Along with, one major constraint is that out of 360 days of growth period, only $12 \%$ of cane weight and $15 \%$ of cane height is
Volume 8 Issue 2 - 2018

\author{
Pushpa Singh, Rama Kant Rai \\ ICAR-Indian Institute of Sugarcane Research, India
}

Correspondence: Pushpa Singh, ICAR-Indian Institute of Sugarcane Research, Lucknow, 226002, India, Email parampushpa@gmail.com

Received: November I, 2017| Published: March 15, 2018

achieved up to 210 DAP (till $\mathrm{T}_{\max }$ ). Rest of the photo-assimilates are diverted towards growth of leaves and tiller numbers. Though these tillers are carried forward till $\mathrm{T}_{\max }$ but about $50-60 \%$ of them die later during the growth process and don't contribute towards NMC.

7. Less cane weight and cane height till 210 DAP are resultant of poor canopy development and its coverage due to poor initial plant population, reduced leaf area and drooping leaf architecture.

8. Such as architecture in small clumps, causes shading effects, lower radiation use efficiency and net assimilation rates.

9. Thus poor and delayed germination, poor initial plant population, poor diversion of photo assimilates towards cane weight and height till 210 DAP followed by severe tiller mortality reduces the clump size and causes great loss in accumulated dry matter.

10. Overall impact of small clumps with drooping leaf architecture limits the sinks strength and it capacity, resulting in poor biomass and sugar contents.

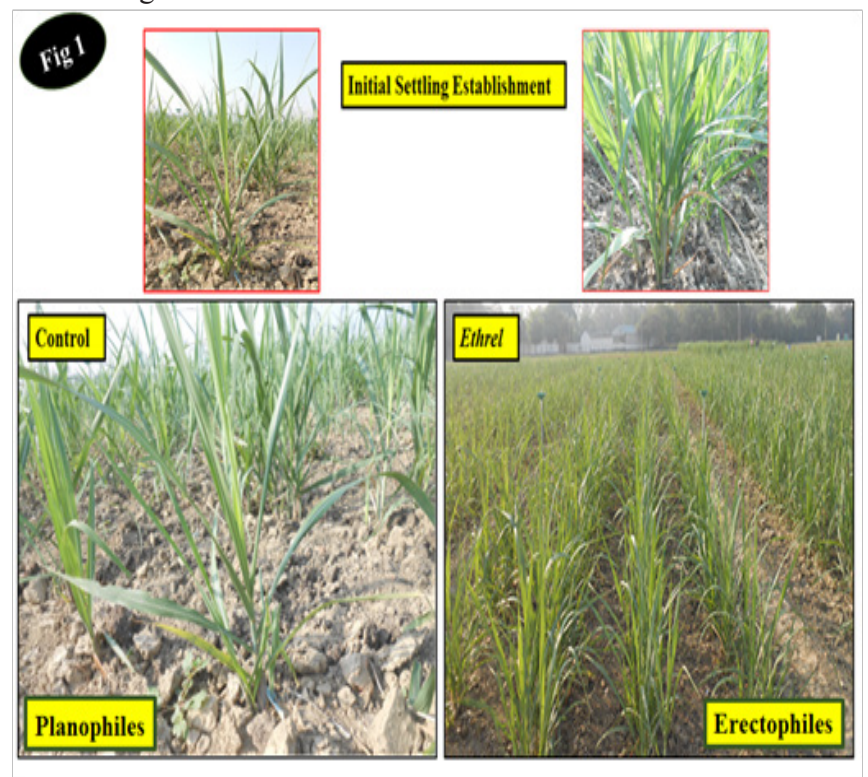

Figure I Uniform and robust settling establishment through Ethrel application in spring planted sugarcane. 
The physiological barriers in sugarcane can be addressed under the dynamic balance of axillary bud differentiation, above ground and below ground growth for inducing architectural changes in plant parts vis a vis leaves, stems and roots. This is required to be initiated at the germination stage itself. As sugarcane is a vegetative crop, propagated through axillary bud on three budded sets, the delay in germination is required to be addressed through enhancing the heterotrophic to autotrophic transitions. Instead of duration of 45 days, the germination process needs to be reduced to 7 days. This shall render the establishment of higher settlings at an early stage (45 and 90 DAP) unlike under normal conditions where the settling numbers are few due to which the canopy development is poor from this stage itself. Smart canopy development and architecture is an important factor determining yield of many crops as a result of interplant competition for light distribution and absorption, particularly in a dense population.

Higher tiller numbers in a clump in sugarcane with altered architecture will improve the source activity and sink strength and its capacity causing improved growth from 90 DAP itself. Smart canopy functions (e.g. photosynthesis) improve as leaf area index (LAI) increases until LAI reaches approximately7 for sugarcane (Saccharum spp. hybrids), but decrease with further increase in LAI. Correspondingly, the number of stalks, intermodal length and their weights in a clump with higher density will increase. In order to attain higher plant density, sugarcane plants with erect leaves and smart canopy will be of prime importance. Photo synthates for sugarcane yield is produced largely by 7-8 leaves below the apical meristem, but these leaves are largely shaded at high plant density, resulting in reduced cane yield. Settling and stalk growth of sugarcane are associated with light interception during the grand growth phase. These processes are affected by number, position and architecture of leaves. Keeping this relationship in mind, it would be possible to achieve a further increase in cane and sugar yield of Saccharum hybrids if plant architecture could be improved through smart canopy development. Plant architecture depends strongly on morphological and physiological parameters such as leaf area, angle and orientation, photosynthesis and dry matter accumulation as shown below in picture.

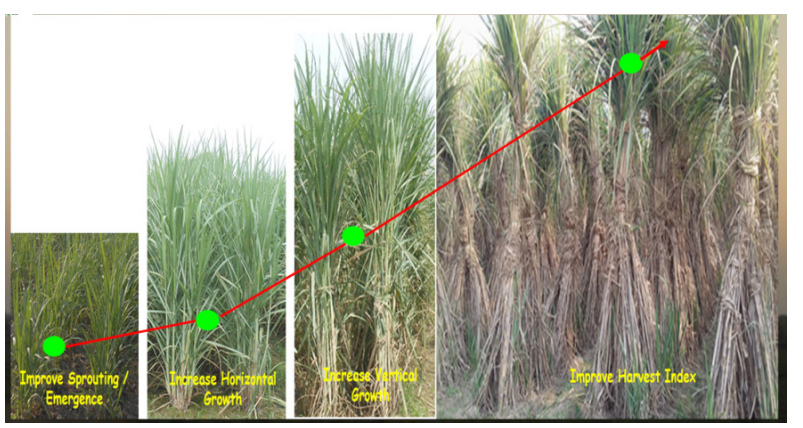

\section{Exploiting Indeterminate Growth Potential-Smart canopy Development}

It is difficult or impossible to collect robust field measurements of so many parameters, because of the costs of time and labor. However an opinion on tailoring sugarcane for smart canopy development is listed below.

a. Early and enhanced germination $(100 \%$ germination within 07 DAP with initial settling population of 40,000 settlings $\mathrm{ha}^{-1}$, instead of $33 \%$ per cent germination with about 40,000 plants ha $^{-1}$ in 45 DAP).

b. The plant population at 90 DAP should be increased to $1,60,000$ $\mathrm{ha}^{-1}$ with improved canopy development and altered leaf and root architecture, instead of 60,000-70,000 plants per ha under normal conditions.

c. The plant density at 90 DAP should be extended up to $T_{\max }$ of $6,75,000$ plants per ha at 210 DAP instead of $1,75,000$ plants per ha under normal conditions.

d. Reduce the tiller cessation to $30-35 \%$ instead of $50-60 \%$ after $\mathrm{T}_{\max }$, finally culminating into increased $\mathrm{NMC}$ of about $4.0-4.5 \mathrm{~L}$ per ha instead of $80,000-100,000$ per ha at harvest stage.

e. Along with, of 360 days of growth period, it should also be targeted that about $50 \%$ of cane weight and $45 \%$ of cane height is achieved by 210 DAP instead of only $12 \%$ of cane weight and $15 \%$ of cane height up to 210 DAP (till $\mathrm{T}_{\max }$ ) under normal conditions.

The approach shall lead to bigger clumpssize with erect leaf architecture, smart canopy delimiting the sink strength and it capacity resulting in improved biomass and sugar contents. Plant growth hormones (usage of Ethrel and $\mathrm{GA}_{3}$ ) have potentially improved the sett vigour, enhanced its ability to sprout and established uniform and robust settlings in spring planted crop (Figure 1).

\section{Materials and methods}

The work was conducted at Indian Council of Agricultural Research (ICAR)-Indian Institute of Sugarcane Research, Lucknow, India, located at $26^{\circ} 56^{\prime} \mathrm{N}, 80^{\circ} 52^{\prime} \mathrm{E}$ and $111 \mathrm{~m}$ above sea level. This falls in Agro-Eco-region 4 (Northern plain and Central Highlands) and Hot Semi-arid Eco-region with Alluvial-derived (N8D2) soils. ${ }^{1}$ The soil of experimental field was sandy loam (13.3\% clay, $24.5 \%$ silt and $62.2 \%$ sand) of Indo-Gangetic alluvial origin, very deep $(>2 \mathrm{~m})$, well drained, flat and classified as non-calcareous mixed hypothermic udic ustochrept. The climate of experimental site is semi-arid, subtropical with hot dry summers and cold winters. The average monthly minimum and maximum temperature during summer (April to June) range from $18.4^{\circ} \mathrm{C}$ to $43^{\circ} \mathrm{C}$ and in winter (November to February) from $7.4^{\circ} \mathrm{C}$ to $29^{\circ} \mathrm{C}$. The average annual rainfall is $1045.5 \mathrm{~mm}$ and cumulative open pan evaporation is $1750 \mathrm{~mm}$. nearly $72 \%$ of the total rainfall is received through north-west monsoon during July to September. The organic carbon (OC) content of soil was $0.48 \%$ with total nitrogen $0.069 \%$. The available nitrogen $(\mathrm{N})$, phosphorus $(\mathrm{P})$, potassium (K) were 183.7, 18.7, $192 \mathrm{~kg} \mathrm{ha}^{-1}$ in 2012-2013 and 185.6, $18.2,190 \mathrm{~kg} \mathrm{ha}^{-1}$ in 2013-2014.

Sugarcane crops were planted with sugarcane variety CoLk 94184 under autumn, spring and late planted conditions, respectively, at institute farm of Indian Council of Agricultural Research- Indian Institute of Sugarcane Research (ICAR-IISR), Lucknow, India. Both fields with left over wheat stubbles were irrigated and later on prepared with cultivator (once) and harrow (twice). Soil moisture of $16 \%$ was maintained in both fields during planting. Ridges and furrows were laid out at $75 \mathrm{~cm}$ spacing with tractor mounted furrow opener. The opened furrows were treated with Chlorpyriphos $(20 \%$ emulsifiable concentrate) for termites control. 


\section{Crop culture and exogenous applications of Ethrel and GA3 at critical growth stages}

Sugarcane variety CoLk 94184, was planted under seven treatments. The treatments were T1: Unsoaked (Control), T2: Un soaked+Water application, T3: Unsoaked $+\mathrm{GA}_{3}$ application, T4: Water soaked, T5: Water soaked + GA application, T6: Ethrel soaked, T7: Ethrel soaked $+\mathrm{GA}_{3}$ application (Table 1). Prior to planting, sugarcane setts were soaked in Ethrel $100 \mathrm{ppm}$ Ethrel. The setts were left overnight and taken out next morning for planting. They were rinsed in Bavastine (@2 $\mathrm{g} \mathrm{L}^{-1}$ ) prior to their planting in the furrows. The foliar application of $\mathrm{GA}_{3}$ was performed at 90,120 and 150 days after planting (DAP) in T3, T5 and T7. GA 3 were dissolved in $0.5 \mathrm{~cm}^{3}$ in ethanol and diluted with distilled water to a concentration of $100 \mathrm{~m}$ mol m${ }^{-3}$ and applied with knap sac $(5 \mathrm{ml}$ per plant) in between 8.00 $9.00 \mathrm{AM}$, while T2 was applied with an equal quantity of distilled water. The concentration of dissolving solvents was too low for any physiological effect on plants. The total quantity of water application and water used in $\mathrm{GA}_{3}$ solution varied with number of plants in every row. Ethrel and Gibberellic acid were purchased from Chemical Drug House (CDH) Bio chemicals, Analytical Reagent (AR) grade, with minimum assay of about $39 \%$ and $99.9 \%$ respectively. The crops were raised with standard agronomic cultivation practices and recommended doses of $\mathrm{N}, \mathrm{P}$, and $\mathrm{K}$ (150: 80: $\left.80 \mathrm{Kg} \mathrm{ha}^{-1}\right)$. Fertilizers used were urea $(46 \% \mathrm{~N})$, single super-phosphate $(6.8 \% \mathrm{P})$ and Muriate of Potash $(46.2 \% \mathrm{~K})$. One third of N, P and K were applied as basal dressing in furrows at the time of planting. The remainder $\mathrm{N}$ was top-dressed in two equal splits at 45 and 90 DAP. Both the crops received a total of four irrigations and three inter-cultural operations. Application of insecticides was made as per recommendation for the region. The plants in all the treatments were free of pests and diseases during the experiments.

Table I Mode/Time of application of PGR at different sugarcane growth stages

\begin{tabular}{|c|c|c|c|}
\hline $\begin{array}{l}\text { Crop Growth } \\
\text { stage }\end{array}$ & $\begin{array}{l}\text { PGR } \\
\text { used }\end{array}$ & Concentration(ppm) & Mode / Time of application \\
\hline At planting & Ethrel & 100 & Overnight soaking of sugarcane setts in $100 \mathrm{ppm}$ Ethrel \\
\hline 60 DAP & Ethrel & 100 & Foliar application 100 ppm Ethrel solution \\
\hline 90 DAP & GA3 & 35 & $\begin{array}{l}\text { Foliar application of GA3 at specific leaf sites in morning (9am-I lam) or in evening } \\
\text { (after } 4 \mathrm{pm}) @ 35 \mathrm{ppm}\end{array}$ \\
\hline I20 DAP & GA3 & 35 & $\begin{array}{l}\text { Foliar application of GA3 at specific leaf sites morning (9am-I lam) or in evening } \\
\text { (after } 4 \mathrm{pm}) @ 35 \text { ppm }\end{array}$ \\
\hline I50 DAP & GA3 & 35 & $\begin{array}{l}\text { Foliar application of GA3 at specific leaf sites morning (9am-I lam) or in evening } \\
\text { (after } 4 \mathrm{pm}) @ 35 \text { ppm }\end{array}$ \\
\hline
\end{tabular}

\section{Bud sprouting, initial shoot numbers determination and biochemical analysis of cane}

Sprouting \% was calculated by counting number of sprouted buds out of the total planted buds. The buds with initial shoot protrusion of at least $2 \mathrm{~mm}$ in length were considered to be sprouted Rai \& others ${ }^{2}$ Bud moisture, bud dry weight and relative growth rate (RGR) were recorded with 45 buds scooped from 15 setts from respective treatments. The freshly removed buds were washed thoroughly and dried with Whatman No.1 filter paper for recording fresh weight. Bud dry weight was recorded by drying buds in hot air oven, at $102^{\circ} \mathrm{C}$ for $24 \mathrm{hrs}$ and $80^{\circ} \mathrm{C}$ for 72 hours, till constant weight. RGR was computed using the formula

$$
\ln \mathrm{W}_{2}-\ln \mathrm{W}_{1} / \mathrm{t}
$$

Where $\ln \mathrm{W}_{1}$ is initial bud dry weight and $\ln \mathrm{W}_{2}$ is bud dry weight attained after time $(\mathrm{t})$ in days, at 20 and 45 DAP. The numbers of settlings sprouted per plot were counted manually for recording initial plant population.

Freshly sampled bud tissues were chopped and homogenized to prepare $10 \%$ homogenate in a chilled pestle and mortar with chilled distilled water. The homogenate was filtered through four layers of cheese cloth and then centrifuged at $8000 \mathrm{~g}$ for $20 \mathrm{~min}$ at $4^{\circ} \mathrm{C}$. The supernatant obtained after centrifugation was used for estimation of reducing sugars, sucrose and total phenolic contents. Estimation of reducing sugar was done according to method of Nelson ${ }^{3} \&$ Somogyi,
1945. Sucrose was estimated by resorcinol Thio urea method described by Roe \& Papadopoulos. ${ }^{4}$ Protein was estimated by method of Lowry \& others ${ }^{5}$ and acid invertase activity was assayed by method of Hatch \& Glasziou. ${ }^{6}$ Total phenolic contents were estimated by method described by Swain and Hillis. ${ }^{7}$ Indole acetic acid (IAA) was determined by method of $\mathrm{Nagar}^{8}$ and IAAO activity was assayed by method of Gordon \& Weber. ${ }^{9}$ The ATP ase activity was assayed by method of Fischer \& Hodges. ${ }^{10}$ The phosphorus estimation was done by following the method of Fiske and Subbarow, 1925. NR activity in vivo and SOD activity were assayed by method of Jaworski and others ${ }^{11} \&$ Beauchamp \& Fridovich ${ }^{12}$ respectively.

\section{Determination of leaf characteristics and shoot development}

The area per leaf was calculated by method described by Lerch $\&$ others. ${ }^{13}$ The total leaf area of individual stalks was obtained by summation of leaf area on each stalk. Leaf area index (LAI) was calculated by multiplying the mean value of leaf area per stalk by number of stalks present in known area. The growth parameters were individually calculated using formulae of $\mathrm{K}$ vet \& others. ${ }^{14}$ Net assimilation rate $(\mathrm{NAR})=\left(\mathrm{W}_{2}-\mathrm{W}_{1}\right)\left(\operatorname{lnL}_{2}-\operatorname{lnL}_{1}\right) /\left[\left(\mathrm{t}_{2}-\mathrm{t}_{1}\right)\left(\mathrm{L}_{2}-\mathrm{L}_{1}\right)\right]$, dry matter produced per leaf area and time units $\left(\mathrm{mg} \mathrm{cm}^{-2} \mathrm{~d}^{-1}\right)^{-2}$. With these values and shoot numbers, NAR was calculated on land area basis.

Leaf area ratio $(\mathrm{LAR})=\mathrm{L} / \mathrm{W}$, relates leaf area with total stalk dry matter $\left(\mathrm{cm}^{2} \mathrm{~g}^{-1}\right)$ 
Leaf area duration $(\mathrm{LAD})=\mathrm{L}_{2}+\mathrm{L}_{1}\left(\mathrm{t}_{2}-\mathrm{t}_{1}\right) / 2\left(\mathrm{~cm}^{2}\right.$ day $) 10^{4}$.

Biomass duration $(\mathrm{Z})=\mathrm{W}_{2}+\mathrm{W}_{1}\left(\mathrm{t}_{2}-\mathrm{t}_{1}\right) / 2$ (g day) $10^{3}$.

Where $\mathrm{W}$ and $\mathrm{L}$ are mean values of dry weight and leaf area at a specific time respectively. $\mathrm{W}_{1}$ and $\mathrm{W}_{2}$ represent initial and final mean values of total dry weight of a stalk. $\mathrm{L}_{1}$ and $\mathrm{L}_{2}$ are the initial and final mean values of leaf area belonging to a stalk over the period $t_{2}-t_{1}$. The growth parameters were calculated at 180 and 270 DAP. The shoot numbers in each plot were counted at 30 days interval till 270 DAP. Stalk length, intermodal length, intermodal girth and intermodal weight were measured with meter scale; vernier calliper and electronic balance in 21 stalks sampled at 180 and 270 DAP.

\section{Determination of total dry matter and juice quality}

Stalk weight was recorded by chopping stalk into small pieces. The chopped pieces were dried in an oven at $80^{\circ} \mathrm{C}$, until constant weight was achieved. Dry matter content $\mathrm{m}^{-2}$ was quantified from total number of stalks in an area of $16 \mathrm{~m}^{2}$ selected from each plot at 180 , and 270 DAP. Cane juice quality was analysed from total number of stalks harvested from an area of $16 \mathrm{~m}^{2}$ at 270 DAP Meade \& Chen. ${ }^{15}$

\section{Statistical analysis}

Data was analysed using the statistical product and service solution version 16.0 software (SPSS Inc, Chicago, II). One way analysis of variance with Duncan's Multiple Range Test (DMRT) as post hoc analysis was used to compare the means Snedecor \& Cochran. ${ }^{16}$ Graphics were generated using Sigma Plot version 10.0 (System software, Inc., Point Richmond, CA). Regression analysis and correlation coefficients were calculated using MS Excel statistical tools to assess the interrelationships between treatment means across the temperature among different parameters.

\section{Discussion}

Their usage led to significant alteration in leaf orientation (Figure 2), cane length (Figure 3) and root architecture (Figure 4). Architectural alterations caused faster heterotrophic to autotrophic transitions at planting stage (February). This induced high initial plant population (45 DAP), which was followed by induction of smart canopy with increased source activity, above and below ground sink development at $60 \mathrm{DAP}$. The formation of smart canopy was due to development of Electrophiles (leaf angle $73^{\circ}$ ) against planophiles (leaf angle $45^{\circ}$ ) in control (Figure 2). Changes in leaf angle enabled added advantage of enhanced $\mathrm{CO}_{2}$ utilization and radiation use efficiency. The $\mathrm{GA}_{3}$ induced leaf orientation formed a smart canopy and improved dry matter partitioning. Further, leaf erectness also reduced the shading effects amongst the leaf present on a stalk, rendering increase in radiation use by lower leaf laminae of the stalk. $\mathrm{GA}_{3}$ induced branched roots with steep angles $\left(30^{\circ}\right)$, threefold increase in root weights and root hair development, sustained the nutrient requirement of increased shoot population. As a result, net assimilation rates $\left[0.65\left(\mathrm{~cm}^{2} \mathrm{~d}^{-1}\right)^{2}\right]$, leaf area ratio $\left(16 \mathrm{~cm}^{2} \mathrm{~g}^{-1}\right)$ and leaf area duration $\left[55\left(\mathrm{~cm}^{2} \mathrm{~d}\right) 10^{4}\right]$ enhanced, leading to increase in internodal numbers, length and their weight. At grand growth and harvest stage, a $\mathrm{T}_{\max } 5.37$ lakhs shoots ha $^{-1}$ with NMC of 3.01 lakhs ha ${ }^{-1}$ with Ethrel and GA $_{3}$ was obtained against $_{\max } 2.13$ lakh shoots ha ${ }^{-1}$ in control with $\mathrm{NMC}$ of 1.32 lakhs shoots $\mathrm{ha}^{-1}$. The application led to significant increase in cane yield of 255 tha $^{-1}$ (per cane weight $847 \mathrm{~g}$ ) against a cane yield of 84.69 tha $^{-1}$ in control (per cane weight $640 \mathrm{~g}$ ). The large accommodation of stalks in limited ground area with Ethrel and $\mathrm{GA}_{3}$ is explained to be due to the development of smart canopies supported by a robust root system, where each plant occupied merely $331 \mathrm{~cm}^{2}$ ground areas against $800 \mathrm{~cm}^{2}$ in control. The architectural alterations through PGR in sugarcane crop increased cane yield from $70-85$ tha $^{-1}$ to 255 tha $^{-1}$ in spring planted sugarcane crop. ${ }^{17-20}$

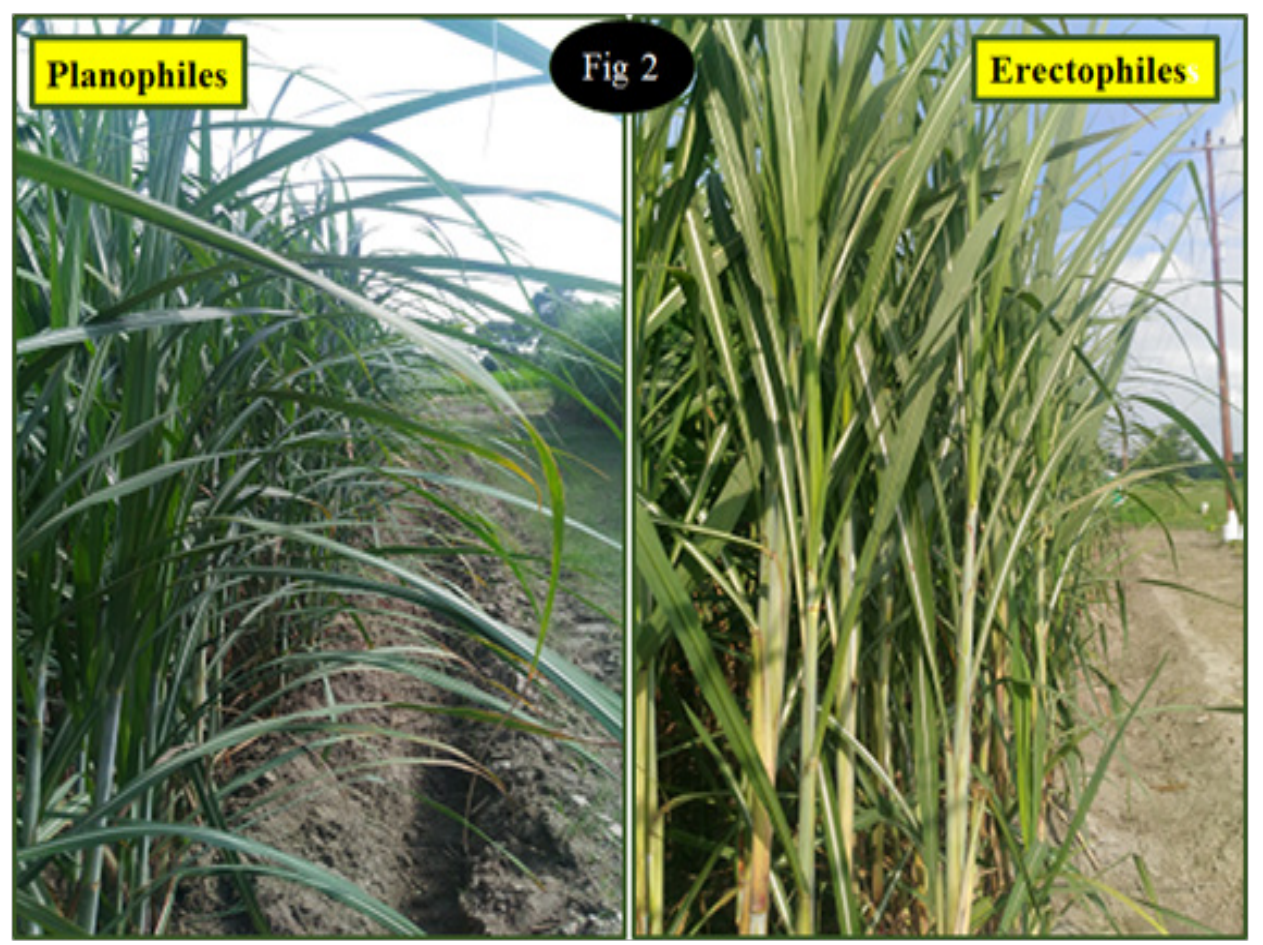

Figure 2 Leaf arrangement alterations through Ethrel and GA3 application in spring planted sugarcane. 


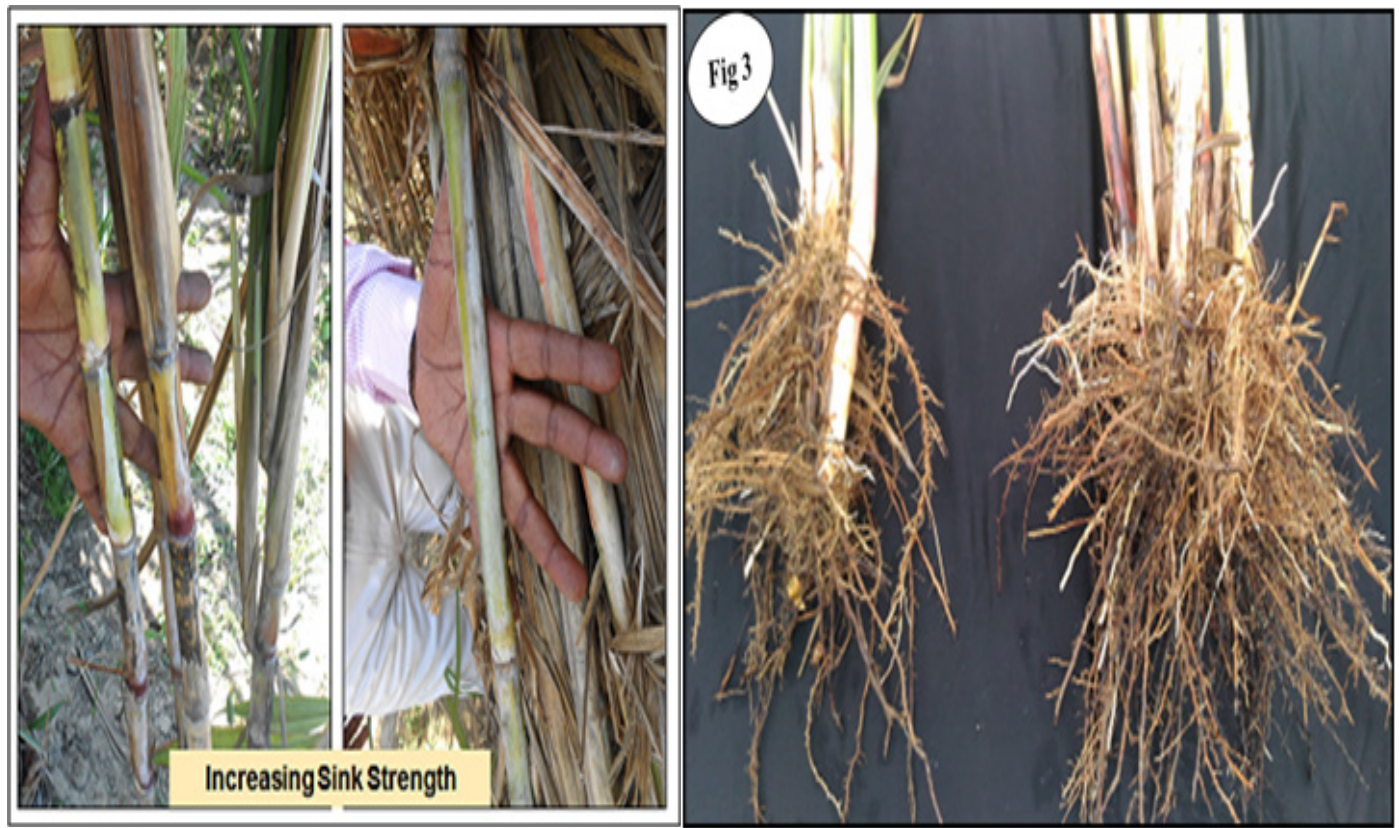

Figure 3 Root architectural alterations through Ethrel and GA3 Application in Spring Planted Sugarcane.

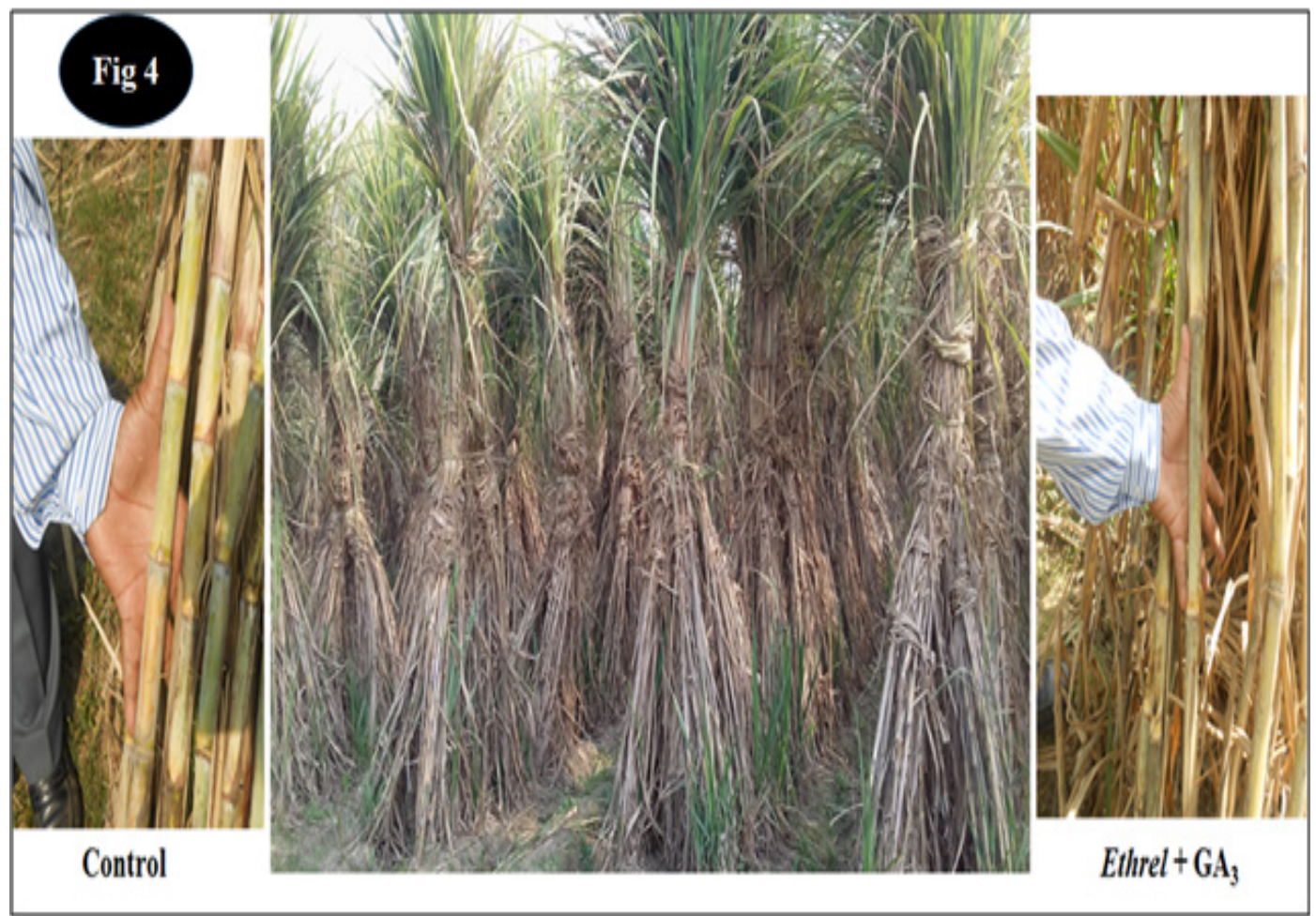

Figure 4 Breaking yield barriers -Through robust shoot numbers and cane length alterations impacted by Ethrel and GA3 in spring planted sugarcane.

\section{Acknowledgment}

None.

\section{Conflict of Interest}

None.

\section{References}

1. Sehgal JL, Mandal DR, Mandal C, et al. Agro-ecological regions of India. NBSS \& LUP, 1990, Nagpur, India.

2. Rai RK, Singh P, Srivastava AK, et al. Modulation of low-temperatureinduced biochemical changes in bud and root band zones of sugar cane sets by potassium, zinc, and Ethrel for improving sprouting. $J$ Agric Food Chem. 2008;56(24):11976-11982. 
3. Nelson NA. Photometric adaptation of Somogyi method for the determination of glucose. J Biol Chem. 1944;153:375-380.

4. Roe JH, Papadopoulos NM. The determination of fructose-6-phosphate and fructose 1, 6-diphosphate. J Biol Chem. 1954; 210(2):703-708.

5. Lowry $\mathrm{OH}$, Rosebrough NJ, Farr AL, et al. Protein measurement with Folin-phenol reagent. J Biol Chem. 1951;193(1):265-275.

6. Hatch MD, Glasziou KT. Sugar accumulation cycle in sugarcaneII Relationship of Invertase Activity to Sugar Content \& Growth Rate in Storage Tissue of Plants Grown in Controlled Environments. Plant Physiol. 1963;38(3):344-348.

7. Swain T, Hillis WE. The phenolic constituents of Prunus domestica I. The quantitative analysis of phenolic constituent. J Sci Food Agric.1999;10:63-68.

8. Nagar PK. Changes in abscisic acid, phenols and indole acetic acid in bulbs of tuberose (Polianthes tuberosa L.) during dormancy and sprouting. Sci Hortic. 1995;63(1-2):77-82.

9. Gordon SA, Weber, RP. Colorimetric estimation of indole acetic acid. Plant Physiol. 1952;2126(1):192-195.

10. Fischer J, Hodges TK. Monovalent ion stimulated adenosine triphosphatase from oat roots. Plant Physiol. 1959;44(3):385-395.

11. Jaworski EG. Nitrate reductase assay in intact plant tissue. Biochem Biophys Res Commun. 1971;43(6):1272-1279.

12. Beauchamp C, Fridovich I. Super oxide dismutase: Improved assays and assays applicable to acrylamide gels. Anal Biochem. 1971;44(1):276287

13. Lerch GR, Reyes R, Garcia R, et al. Growth, development and variation of the refractive index (Brix) in six varieties of sugar cane. Cien Agric. 1977;1:79-105.

14. Kvet J, Ondok JP, Necas J, et al. Methods of growth analysis. Plant Photosynthetic Production. The Hague. The Hague Publisher. 1971;343-391.

15. Meade GP, Chen JGP. Cane Sugar Handbook. Ed 10. A Wiley Inter Science Publication, John Wiley and Sons, 1977, New York.

16. Snedecor GW, Cochran WG (1967) Statistical Methods. Oxford and IBH Publ, India, pp. 381-418.

17. Rama Kant Rai, Nidhi Tripathi, Deeksha Gautam, et al. Exogenous application of Ethrel and Gibberellic acid stimulates physiological growth of late planted sugarcane with short growth period in sub-tropical India, Journal of Plant Growth Regulation. 2016;36(2);472-486.

18. King EJ. The Colorimetric determination of phosphorus. Biochem J. 1932;26(2): 292-297.

19. Ramakant Rai, Pushpa Singh. Padap Vridhi hormones se ganna paidawaar mei vridhi, Kheti, July issue, 2016; pp. 38-40.

20. Ramakant Rai, Pushpa Singh. Bumper rise in autumn and late planted sugarcane yields through plant growth regulators", Indian Farming. 2016;66(7);29-32. 